\title{
PERFORMANCE MEASUREMENT OF INFORMATION TECHNOLOGY GOVERNANCE IN BRAZILIAN FINANCIAL INSTITUTIONS
}

\author{
Sara C. Boni Barbosa \\ Ildeberto Aparecido Rodello \\ Silvia Inês Dallavalle de Pádua \\ University of Sao Paulo, USP/FEARP, Ribeirão Preto, SP, Brazil
}

\section{ABSTRACT}

Information technology governance is a process by which organizations align their information technology operations and services with their performance goals and strategic objectives and assess the results. The financial sector has benefited greatly from the development of information technology, primarily in bank automation. There are few research works aimed at describing information technology governance, and there are even fewer in the financial sector. This paper is aimed at measuring information technology governance in financial institutions using the methodology proposed by Weill and Ross (2004). The sample consisted of sixty professionals from financial institutions operating in Brazil. The average performance score was approximately 79.6, showing that the organizations studied have not achieved maximum performance (100), although many are very close to it. This paper describes an original empirical study of Brazilian financial institutions concerning information technology management performance. The survey investigates not only the context of performance, but also the importance that the organization places on each item related to information technology governance aligned with business needs and goals.

Keywords: Information technology governance; Information technology; Corporate governance; Financial institutions.

Manuscript first received/Recebido em: 15/08/2012 Manuscript accepted/Aprovado em: 30/04/2014

Address for correspondence / Endereço para correspondência

Sara C. Boni Barbosa is a project management specialist at CIELO S.A. She has a bachelor's degree in Business Administration from the University of Sao Paulo College of Economics, Business and Accountancy at Ribeirão Preto (FEARP) and is a post-graduate student of project management at Berkeley University. E-mail: sara_cbb@hotmail.com

Ildeberto Aparecido Rodello is a professor of Information Systems at the University of São Paulo (USP) College of Economics, Business and Accountancy at Ribeirão Preto (FEARP). He has a Ph.D. in Applied Sciences (Virtual Reality) and develops research on topics such as Information Systems, Open Source ERP Systems and Distance Learning. He lectures on information systems development, e-commerce, distance learning and organizational change through information technology. E-mail: rodello@ fearp.usp.br

Silvia Inês Dallavalle de Pádua is a professor of Information Systems at the University of Sao Paulo College of Economics, Business and Accountancy at Ribeirão Preto (FEARP). She has a Ph.D. in Engineering and develops research on topics such as Business Process Management and Information Systems. She lectures on information system development and business process management. E-mail: dallavalle@ fearp.usp.br University of São Paulo Business Administration Department - College of Economics, Business and Accountancy at Ribeirão Preto (FEARP/USP). Address: Avenida dos Bandeirantes, 3900, Monte Alegre, Ribeirão Preto - SP - Brazil - 14040-900 


\section{INTRODUCTION}

Obtaining accurate information as soon as possible is recognized by organizations as an important tool for competitive survival and is considered one of the most important strategic resources (Weill \& Ross, 2004). In the global context of rapid changes and fast communication, information has become a strategic asset, and information technology (IT) is an important contributor to the success of the economy (Afzali et al., 2010; Ayat, Masrom, \& Sahibuddin, 2011; Krey et al., 2011). According to Khadra et al. (2009), enterprises understand the growing importance of IT and consider it a treasure in enhancing their competitive position and adding value to their business. In addition, IT usage provides benefits at several levels of businesses, government and society (Bin-Abbas \& Bakry, 2014).

IT is an important asset for supporting organizational processes. It is crucial for growth and innovation and for consolidation of fusions and acquisitions. However, according to Albertin and Albertin (2008), consistently determining the benefits of IT presents some challenges for managers due to the particularities of IT management. The problem involving IT theory and practice is how to maximize its potential (Wilkin \& Chenhall, 2010). According to Nfuka and Rusu (2011), an understanding and familiarity with IT is essential to developing the alignment between business strategy and IT.

In IT governance (ITG), CIOs must manage not only activities that are directly related to IT but also the connections between IT and organizational strategy (Schwarz \& Hirschheim, 2003). According to Weill and Ross (2004), ITG is related to the definition of criteria for the management and assessment of IT investments. It can be considered an extension of Corporate Governance (CG), and because IT expenses have surpassed more than half of the capital of large companies (according to the US Department of Commerce (Economics \& Statistics Administration, 2003)), managers are deeply concerned (Jordan \& Musson, 2004).

According to Gheorghe et al. (2009) and De Haes and Grembergen (2008), ITG is defined as procedures and policies established to guarantee that an organization's IT portfolio supports their objectives and strategies. To Butler and Butler (2010), and Lin, Chou and Wang (2011), ITG is mandatory for organizations due to the significant risks associated with ubiquitous business IT. ITG is a high priority for many organizations and high-level IT Governance models are being created (De Haes \& Grembergen, 2008). To Simonsson, Johnson, and Ekstedt (2010), it is possible to identify a relationship between ITG performance and business performance, although there are no quantitative studies to prove its existence.

In a study conducted by Weill and Ross (2005), companies that effectively govern IT can achieve $20 \%$ higher profits than other companies operating with similar strategies. Companies that effectively govern IT also have outcomes greater than their own capital and market capitalization growth. In this context, IT Governance helps to better control their projects.

There is a link between high-level IT Governance performance results and high financial performance (Lunardi et al., 2014). Effective ITG aligns IT investments with business priorities, determines who makes the decisions about IT, and attributes the responsibility for the results. For financial institutions, it is particularly important to mitigate business risks and add value through IT usage (Gheorghe et al., 2009) in order to avoid fraud or guarantee forms to identify customers.

According to Gheorghe et al. (2009), such demands have had an impact on ITG in financial institutions. This includes credit achievement, which now is measured by considering an organization's capacity to protect its assets, most of which are intangible. ITG is directly related to information security requirements and implementation of control policies to 
guarantee that managers are truly aware of the company's situation and are able to report it to the market, investors and other interested parties (stakeholders), thus reflecting their risk scenario, particularly in operations (Peck, 2006).

There are several studies portraying ITG performance, such as the ones by Weill and Ross (2004, 2005), Jairak and Praneetpolgrang (2013), Albertin and Albertin (2008), Arruda and Silva Filho (2006) and Lunardi et al. (2014), among others. "However, having developed a high-level IT governance model does not imply that governance is actually working in the organization" (De Haes \& Grembergen, 2008).

According to Jong et al. (2010), Ko and Fink (2010), Krey et al. (2011), and Wilkin and Chenhall (2010), IT Governance is still a new and not fully developed field. It is necessary to develop additional work on theoretical and practical perspectives. In addition, one part of the sector that has benefited the most from IT development: bank automation. It is expected that bank automation's high investments in IT follows a mature management system, i.e., a system that has implemented IT Governance.

Through the adaptation of research conducted in 2002 by Weill and Ross (2004), this study is aimed at answering the following question: "What is the performance of IT governance in financial institutions operating in Brazil?" The main goal of this study is to measure the performance of ITG in financial institutions in Brazil, thereby making a future benchmark for worldwide results possible.

To explore this goal, the following themes are conceptually approached: Corporate Governance (section 2), IT Governance (section 3), and Financial Institutions and their informatics process in Brazil (section 4). In addition, this paper presents the study's methodology (section 5) and a discussion of the results (section 6).

\section{CORPORATE GOVERNANCE}

To understand IT Governance, it is necessary to first comprehend the concept of Corporate Governance (CG), the system by which organizations are directed and controlled. CG first appeared in the mid-1990s and was aimed at overcoming the conflict among agencies resulting from the separation of property and entrepreneurial management (IBGC, 2009)

In this an unreliable and biased scenario, CG is intended to defend the adoption of key guidelines, such as transparency, income statements, equity, and corporative responsibility, to align management and stockholder interests and to avoid the abuse of authority, frauds, and strategic mistakes (IBGC, 2009).

Corporate Governance is the system by which companies are directed, monitored and stimulated, and it involves relationships among owners, boards of directors, and control institutions. Governance is a mechanism for monitoring the actions, policies and decisions of corporations and involves the alignment of stakeholder interests (OECD, 2004). Corporate Governance best practices convert principles into recommended objectives and align interests to preserve and enhance the value of the organization, thereby making it easier to access capital and increase longevity (IBGC, 2009).

The level of CG can be considered a parameter of the financial market. According to the research conducted by McKinsey and presented by Weill \& Ross (2004), professional investors are ready to pay more to invest in companies with high governance standards, varying from $13 \%$ in North America to $25 \%$ in Asia. Large corporations attribute the same weight to CG as 
they do to financial indicators when making investment decisions (Weill \& Ross, 2004). According to the Brazilian Institution of Corporate Governance (IBCG, 2009), the World Bank and the International Monetary Fund "consider the adoption of best practices in corporate governance as part of the recovery of world markets weakened by the crisis of their respective capital markets."

\section{INFORMATION TECHNOLOGY GOVERNANCE}

In general, CG approaches the relationship of six major types of assets in a corporation (human resources, financial, physical, intellectual property, information, and relationship). Due to low morale in the 1990s, entrepreneurs adapted to behavior change and required higher control, transparency and predictability, thereby influencing new generations of management tools. A succession of events made IT Governance essential in business (Mansur, 2007): the " $2 \mathrm{k}$ bug", which made clear the lack of knowledge about IT assets and how they impacted organizations; the "internet bubble", which showed budget concerns; and cases of fraudulent information in the financial sector, which showed the inefficiency of the existing rules and resulted in the creation of the Sarbanes-Oxley Act (SOX) $)^{2}$ (Wilkin \& Chenhall, 2010).

ITG is presented in a series of papers (Albertin and Albertin (2008), Schwarz and Hirschheim (2003), Van Grembergen (2004), Weill and Broadbent (2003), and Wilkin and Chenhall (2010)) as always being connected to decisions regarding the use and management of IT to overcome the information problems mentioned above.

IT governance has been used to describe the policies, structures and processes of management that involve IT functions as a way to obtain a return on IT investments (Wilkin \& Chenhall, 2010). According to Weill and Ross (2004), IT Governance is a process by which organizations align their IT actions with their performance goals and assess the consequences and results of these actions. Table 1 summarizes the major goals and advantages of effective ITG:

\footnotetext{
${ }^{1}$ According to Peron (2009), a phenomenon was observed between 1995 and 2001, when dot-com companies were highly estimated in the stock exchange, stimulated by the promise of huge profits from this newly created virtual world.

${ }^{2}$ The Sarbanes-Oxley Act strictly regulated the corporate world, establishing a new logic for the principles of CG and presenting itself as a way to renew best practices of legal conformity, responsibility for accounts, transparency and justice (IBGC, 2007).
} 
Table 1. Goals and advantages of IT governance.

Goals of IT Governance: $\quad$ IT Governance enables companies:

- To facilitate decisions about IT • To measure and audit the execution and investments. quality of services

- To streamline IT operations and/or IT

- To make feasible the follow-up of internal services and external contracts

- To improve the level of quality of IT services

- To define conditions for the effective performance of management based on consolidated quality concepts.

- To establish and maintain good relationships with clients and suppliers

- To maximize the use of resources.

- To optimize costs.

- To manage risks (to identify, analyze, and mitigate them)

- To establish and maintain conformity with rules and regulations

- To promote integration between Business and IT

\section{Advantages of IT Governance:}

- Alignment of IT strategy with business fields;

- Better quality and capacity for new models of business or adjustments in the current models

- Maintenance of business risks under control;

- Mediation and ongoing improvement of IT control;

- Better transparency of IT activities

- To generate value for the company.

Source: Adapted from Tapajós (2008)

ITG is comprehensive and focused on transforming and directing IT resources towards current and future business requirements, both internal and external (Van Grembergen, Haes, \& Guldentops, 2004; Wilkin \& Chenhall, 2010). Weill and Ross (2004) summarized the key decisions about ITG in five domains (Table 2).

The decisions regarding IT principles clarify the strategic role of IT business, establishing the guidelines for other decisions. Architecture decisions change IT principles into requirements for integration and standardization, achieving all of the technical specifications necessary to promote the required skills. Infrastructure decisions generate the necessary IT skills, while decisions involving the necessity of application use these skills. Finally, investment decisions mobilize and prioritize resources to transform system principles (Weill \& Ross, 2004, 2005). 
Table 2. Major decisions about IT governance.

\section{IT principles:}

High-level decisions about the strategic role of IT in the business.

\section{IT architecture:}

Integrated set of technical choices to guide the organization in satisfying business needs.

\section{IT infrastructure:}

Centrally coordinated, shared

IT services that provide the foundation for the enterprise's IT capability

\section{Business application needs:}

Business requirements for purchased or internally developed IT applications.

Source: Weill and Ross (2004, p. 29)

Table 2 also depicts how IT is strongly related to business processes and strategic planning and, as highlighted by Weill and Ross (2004), how the IT field is not solely responsible for the effective use of data and IT. The responsibility has to be shared with company leaders.

In general, ITG is related to two main factors: IT must add value to the business in terms of strategic alignment, and the risks of IT must be minimized, which requires the management of company resources. Both factors need to be supported by indicators and measures to guarantee that the intended results are achieved (Van Grembergen, Haes, \& Guldentops, 2004; Wilkin \& Chenhall, 2010).

Value delivery and risk management are considered dimensions of result or governance purpose. Strategic alignment, resource management and performance measurement are understood as generator domains. When these three domains are well managed, they become feasible for the other two result domains (ITGI, 2003).

Although many CEOs agree with the importance and necessity of IT Governance, its implementation is still considered a challenge in most corporations (Lunardi et al., 2007). Studies show that it is necessary to have a holistic approach to the knowledge involving ITG, such as resources, staff, and innovation. Because ITG is complex and dynamic, it consists of a series of interdependent subsystems that deliver a more powerful whole (Van Grembergen, Haes, \& Guldentops, 2004).

The answer to effective IT Governance implementation lies in a set of practices that refer to the structures, processes and forms of relationships (mechanisms of integration), as shown in Figure 1 (Van Grembergen, Haes, \& Guldentops 2004). 


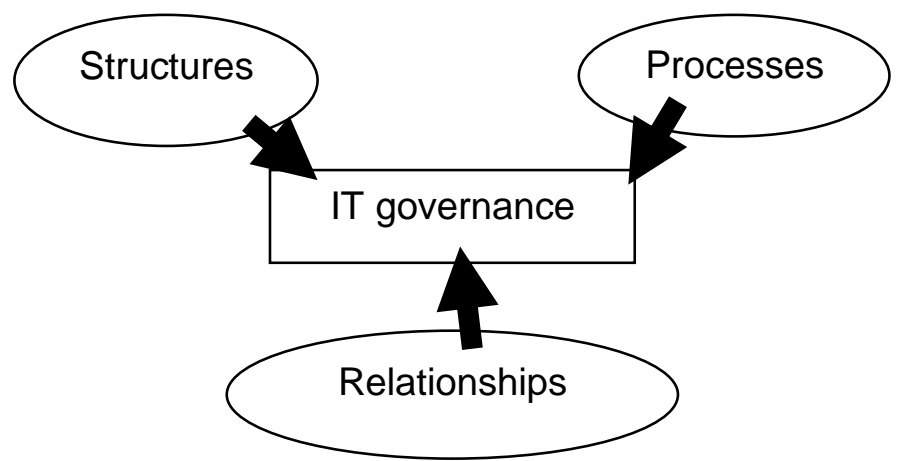

Figure 1. IT Governance mechanisms

Source: Adapted from Van Grembergen, Haes, \& Guldentops, 2004, p. 5

Structure arrangements consist in organizing the units of a company and determining the ones responsible for IT decision-making, such as the creation of committees and strategic positions in IT (Van Grembergen, 2004).

This dimension of the process focuses on the implementation of IT management techniques and the fulfillment of pre-established procedures such as IT strategies and policies. These practices provide acceptable measures for IT operations, such as clarity and transparency for governance. Implementation can be supported by using the Balanced Scorecard, COBIT (Control Objectives for Information and related Technology) (COBIT 5, 2013), and ITIL (Information Technology Infrastructure Library) (ITIL, 2013), among others (Bowen, Cheung, \& Rohde, 2007).

The integration mechanisms used determine the relationships and practices that make internal or external agents more involved with IT actions and consequences, thus promoting a better understanding and alignment among mechanisms (Lunardi et al., 2007).

In addition to being more accepted by stakeholders, this set of models provides a more unified language and larger share of commitments. Stakeholders are better able to guide investments and monitor performance. This includes financial market analysts, a stakeholder group that is increasingly monitoring every data of IT "investment-performance" to provide better guidance to potential investors (ITGI, 2008).

Therefore, these implementations are guided not only by the company's internal characteristics but also by market requirements. From acts such as SOX to certifications such as ISO 20000, companies need to be regulated so that they can ensure their reliability in the market, among other factors. Failures in IT initiatives can lead to up to a $2 \%$ fall in the price of company stocks, according to a September 2009 report from a North American researcher (Young, 2009).

\section{FINANCIAL INSTITUTIONS AND INFORMATION PROCESS}

According to the Brazilian Bank Federation (FEBRABAN, 2010a), financial institutions are defined as follows: 
Legal or private entities whose major or secondary activity is the collection, intermediation or investment of financial funds of their own or of third parties, in national or foreign currency, and the custody of property value of third parties.

The Brazilian Bank Association also noted that in 2008, multiple and commercial banks were responsible for more than $80 \%$ of all assets in the National Financial System. As such, most of the information is concentrated in the bank sector rather than in other financial institutions (ABBC, 2008).

In Brazil, bank automation follows three major points: the implementation of automation systems for administrative control, management support, and customer service. The concentration of financial capital, the fierce competition among banks, the different service offerings in the market, and the accounting standardization implemented by the Central Bank all enabled the first automation experiences in the late 1960s (Dalmazo, 2005).

In the 1960s, the first Data Processing Centers (DPC) and accounting standardization were created. Made up of mainframes, the DPC stored all data from agencies' daily financial operations (Blass, 1993). The same group started to operate investments, financing, brokerage, property finance, security and leasing (Dalmazo, 2005).

In the 1970s, sub-centers of data input were implemented that filtered the information and sent it back to the DPC. After a short time, all data were automatically transferred to the processing centers. The first management decision support systems then appeared (Blass, 1993).

In the 1980s, the use of magnetic cards began. The use of self-services also grew, including the use of automatic teller machines that were connected to banks, independent of place and time, and the so-called online banks, which offered customer service through automatic systems, completely changing the tellers' operation routine. Thus, Multiple Banks ${ }^{3}$ were created. The advance of the technological standard was based on intensive, flexible and computer technologies in information and communication. As a result, a myriad of foreign banks came to Brazil (Dalmazo, 2005).

In the 1990s, online systems were used internally by banks, decreasing or even eliminating the manual labor of some daily processes in the agencies (Blass, 1993). Since 1993, the number of self-service withdrawals and deposits in checking and savings accounts has been higher than those completed by agencies (Blass, 1993). The home banking system and the "pocket bank" were also created in the 1990s to make remote purchases and payments (Blass, 1993).

After the Brazilian Central Bank's reform in 2001 and 2002, the focus was shifted to risk management. The Brazilian Payment System enabled the transfer of resources, processing and payment settling to individuals, companies, the government, the Central Bank, and financial institutions. The Transfer of Reserves System introduced Brazil to a group of countries in which inter-bank transfer of funds can be performed in real time, unconditionally and irrevocably. The Transfer of Reserves System also guarantees security and reliability, helping with the reduction of Risco Brasil (country risk) (DEBAN, 2009).

\footnotetext{
${ }^{3}$ A multiple bank is a private or public financial institution that performs lending, borrowing and accessory transactions by means of commercial, investment and/or development portfolios, property finance, commercial, credit, finance and investment leases (Banco Central do Brasil [BCB], 2007)
} 
In 2004, bank IT management was still focused on technological aspects and was rarely integrated into the business management model. IT management was made up only of investments in hardware and software (Cordenonsi, 2004).

Considering the strength of globalization and the growth of acquisitions and fusions, Brazilian banks are inclined to have more effective resource management and IT services. The quality of financial services is improved through the development and implementation of internal processes and controls to reduce the operational risk and by meeting the requirements of the market, government, account holders, and shareholders (Canton, 2008; Cordenonsi, 2004). Since 2008, this quality has advanced more than any other sector in terms of maturity in management by Corporate Governance, aside from leading IT Governance implementation (Canton, 2008).

The COBIT is widely used by areas of IT and internal auditing in Brazilian financial institutions because the Central Bank follows this model for technical reference in the supervision of bank institution IT. Another market requirement, with external function restrictions, is that these financial institutions operate according to a regulation imposed by the government. The consequences of their actions have implications in their sector as well as political and social implications (Dalmazo, 2005; Toledo, 1993).

In accordance with FEBRABAN (2010b), in 2008 the banking sector's IT budget surpassed R $\$ 16$ billion, presenting an annual growth of $9 \%$. The investments (recorded in the fixed banks) grew 12\%, while current expenses increased $7 \%$. It is interesting to note that in 2008 , these investments represented $40 \%$ of all IT expenses, with amounts dedicated to the acquisition of cutting edge technological equipment and the development of new solutions, while the investments in telecommunications have become smaller and smaller each year (FEBRABAN, 2010b)

Finally, it is possible to imagine that the "bank of the future" will be firmly supported by services coming from mobile platforms and the evolution of these technologies, as well as by telecommunications networks that will ensure a better data flow. Applying the client profile to each integration will be the key to applying technology to services that add intelligence to the most different processes. For example, there are more people using cell phones than there are account holders (CPqD, 2010).

\section{METHODOLOGY}

This study is considered a transversal descriptive survey. According to Malhotra (2001), this type of research is formal and structured and is based on quantitative data. The quantitative method is characterized by the use of quantification in both data gathering modalities and their treatment using statistics techniques (Richardson, 1999).

Our data collection method was a survey, a procedure of collecting primary data from individuals. We used an electronic survey of self-managed questionnaires, and the survey was conducted without the physical presence of a researcher.

The data collection instrument was based on a questionnaire developed and evaluated by Weill and Ross $(2004,2005)$ to assess IT Governance performance. In addition to the questions proposed by Weill and Ross, the questionnaire has two more parts. Table 3 summarizes the structure of the survey questionnaire, which has a total of 18 questions: 
Table 3 - Set of variables of the survey instrument

\begin{tabular}{cccc}
\hline Group & Surveying goal & Source & $\begin{array}{c}\text { Number of } \\
\text { questions/statements }\end{array}$ \\
\hline $\begin{array}{c}\text { Organization } \\
\text { classification }\end{array}$ & $\begin{array}{c}\text { To trace the organization } \\
\text { profile }\end{array}$ & $\begin{array}{c}\text { Instituto Brasileiro de } \\
\text { Geografia e Estatística } \\
\text { [IBGE] (2004) }\end{array}$ & 4 \\
$\begin{array}{c}\text { Functional } \\
\text { classification of } \\
\text { the interviewed }\end{array}$ & $\begin{array}{c}\text { To trace the profile of the } \\
\text { respondent professional }\end{array}$ & $\begin{array}{c}\text { Arruda and Silva } \\
\text { Filho (2006) }\end{array}$ & 6 \\
$\begin{array}{c}\text { Relevance and } \\
\text { success of the IT } \\
\text { activities }\end{array}$ & $\begin{array}{c}\text { To obtain information } \\
\text { about ITG performance }\end{array}$ & Weill and Ross (2004) & 8 \\
\hline
\end{tabular}

Our study initially required that information about the respondents be used in the descriptive analysis, forming a data set about the profile of the respondents who participated in it, on behalf of their respective financial organizations. As mentioned above, the group of questions about relevance and success of IT activities is based on the instrument developed and validated by Weill and Ross $(2004,2005)$, which evaluates IT Governance performance.

\subsection{SURVEY MODEL}

The questions related to relevance and success of IT activities are divided into two blocks: relevance and influence. Questions in the "relevance block" evaluate the importance of specific IT results. This block considers the importance of IT. The questions in the "influence block" evaluate which IT governance measure contributes to the achievement of these results (Weill \& Ross, 2005).

Each answer to the questions in the relevance block and the influence block corresponds to a numeric value and block (i.e., Q1 and Q2, respectively), as shown in Table 4:

Table 4 - Numeric value of the questions in the Relevance and Influence blocks

\begin{tabular}{ll}
\hline "Relevance block" $(\mathrm{Q} 1)$ & "Influence block" $(\mathrm{Q} 2)$ \\
\hline No relevance $=1$ & No Success $=1$ \\
Little relevance $=2$ & Little success $=2$ \\
Medium relevance $=3$ & Regular $=3$ \\
Relevant $=4$ & Well succeeded $=4$ \\
Very relevant $=5$ & Very well succeeded $=5$ \\
\hline
\end{tabular}


The answers that composevariable Q1 attribute value to the answers of variable Q2. The sum of the average of the four objectives is multiplied by 100 (maximum total to achieve) and divided by the companies' maximum score. The same relevance was considered, as was the fact that a company was very successful in every aspect, using a mathematical Equation 1:

\section{$\underline{(\Sigma \mathrm{n}=\mathrm{a}} 4($ Relevant of result $\{\mathrm{Q} 1\}) *$ Influence of IT governance $\{\mathrm{Q} 2\})) * 100$}

$$
(\Sigma \mathrm{n}=1 \text { to } 4(5 \text { (Relevant of result }))
$$

Equation 1 - Calculation formula for performance of IT governance

Source: Weill and Ross (2004)

In a nutshell, the calculation expressed in Equation 1 can be simplified by using the spreadsheet presented in Table 5.

Table 5 - Spreadsheet for the calculation of IT governance performance

\begin{tabular}{|c|c|c|c|c|}
\hline & $\begin{array}{l}\text { How important are the } \\
\text { following outcomes of your } \\
\text { IT governance? }\end{array}$ & & $\begin{array}{l}\text { How does your IT } \\
\text { governance influence } \\
\text { these outcomes? }\end{array}$ & \\
\hline $\begin{array}{l}\text { Cost-effective use of } \\
\text { IT }\end{array}$ & & $X$ & & $=$ \\
\hline $\begin{array}{l}\text { Effective use of IT } \\
\text { for the company's } \\
\text { growth }\end{array}$ & & $X$ & & $=$ \\
\hline $\begin{array}{l}\text { Effective use of IT } \\
\text { for asset utilization }\end{array}$ & & $X$ & & $=$ \\
\hline $\begin{array}{l}\text { Effective use of IT } \\
\text { for } \quad \text { business } \\
\text { flexibility }\end{array}$ & & $X$ & & $=$ \\
\hline Total of Relevance & & & & Total \\
\hline
\end{tabular}

Source: Weill and Ross (2004)

The formula to calculate IT governance performance can be expressed by the reduced form according to Equation 2:

(Total / Total of Relevance) X 20

Equation 2 - Reduced formula for calculation of performance of IT governance Source: Weill and Ross (2005) 


\section{PRESENTATION AND ANALYSIS OF RESULTS}

The questionnaire was available online from April 12, 2010, to June 1, 2010. The web address (URL) was sent to the respondents by electronic mail, and invitation e-mails were sent to representative members from the Brazilian Society for Worldwide Interbank Financial Telecommunication (SWIFT) (FEBRABAN, 2010c). Using the FEBRABAN website, 96 highranking employees from financial institutions operating in Brazil were contacted. A second database of employees from the financial institutions that are part of the housing finance system was also used, and 25 of them were licensed and made available on the Urban Development Ministry's website. Other invitations were made based on random contacts and the academic environment with the participation of former students and the current staff of financial institutions.

\subsection{SAMPLE PROFILE CHARACTERIZATION}

In total, there were 105 answers, out of which 60 were complete and 45 were incomplete. The data were exported to an electronic spreadsheet in which more advanced calculations and tables were made. To facilitate the collection of data, the country/region was not specified. In addition, due to the content of some questions, it was necessary to keep respondents anonymous.

The financial institutions in the sample are classified as follows: $56 \%$ are quasigovernment companies (both public and private capital), $71.5 \%$ are multiple banks with a commercial portfolio, and $86.5 \%$ are institutions that employ more than 100 people and have an annual gross income higher than $\mathrm{R} \$ 2.400 .000,00$ (approximately US $\$ 1.351 .351,35$ in 18th January 2012.)

The respondents' profile classification is as follows: $60 \%$ are part of the operational staff and not in a leadership position, $63 \%$ have been employed in the same organization for more than 5 years, $65 \%$ work in the IT sector, and $74 \%$ interact with the information system on a daily basis, whereas $51 \%$ spend more than 4 hours a day using the information system.

\subsection{BLOCKS OF QUESTIONS ANALYSIS}

The "relevance block" evaluates how the four objectives are considered; that is, it evaluates the importance of specific results (Weill \& Ross, 2004). As follows, each question of the block is analyzed. The element considered to be the most important was the use of IT for the growth of the organization; second, the use of IT for business flexibility; third, to maximize the cost/benefit relationship of the decisions; and fourth, the efficient use of assets.

The "relevance block" reflects the performance companies deliver when using IT in the four questions. It evaluates in what measure ITG contributes to these results (Weill \& Ross, 2004).

The results obtained for each question demonstrated that the sample considers the most successful company to be the one that uses IT to reach organizational growth. Ranked second is the use of IT to maximize the cost/benefit relationship and the use of IT for business flexibility. Ranked last is the use of IT for better asset use.

\subsection{ITG PERFORMANCE RESULTS}

To measure IT governance performance according to the formula given by Weill and Ross (2004) (equation 1), it is necessary to follow some mathematic steps, as shown in Section 5.1 .

Considering that every organization does not give the same importance to the results, the answers to the first question (Table 6) attribute some weight to the answers of the second 
questions (second part of Table 6). The scores considered by the weight of the four questions are added and divided by the maximum score achieved by the company (Weill \& Ross, 2004).

Table 6 - Q1 and Q2 Calculation

\begin{tabular}{|c|c|c|c|c|c|}
\hline \multirow{5}{*}{ 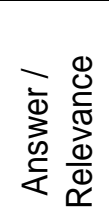 } & Score & Cost/Benefit & Growth & Asset & Flexibility \\
\hline & 1 & 3 & 2 & 2 & 2 \\
\hline & 2 & 0 & 2 & 1 & 1 \\
\hline & 3 & 0 & 1 & 3 & 4 \\
\hline & 4 & 22 & 16 & 25 & 16 \\
\hline \multirow{3}{*}{ Q1 } & 5 & 33 & 37 & 27 & 35 \\
\hline & & 256 & 258 & 248 & 255 \\
\hline & Average & 4,413793103 & 4,448275862 & 4,275862069 & 4,396551724 \\
\hline \multicolumn{2}{|c|}{ Score } & Cost/Benefit & Growth & Asset & Flexibility \\
\hline \multirow{5}{*}{ 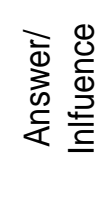 } & 1 & 2 & 1 & 3 & 3 \\
\hline & 2 & 2 & 3 & 2 & 1 \\
\hline & 3 & 6 & 6 & 8 & 7 \\
\hline & 4 & 32 & 29 & 31 & 31 \\
\hline & 5 & 16 & 19 & 14 & 16 \\
\hline \multirow[t]{2}{*}{ Q2 } & & 232 & 236 & 225 & 230 \\
\hline & Average & 4,00000000 & 4,068965517 & 3,879310345 & 3,965517241 \\
\hline
\end{tabular}

Considering Equation 1, the multiplication of the score addition (Q1 and Q2) = 69.77705 , and the addition of $\mathrm{Q} 1=87.67241$. Thus, we have $69.77705 * 100 / 87.67241=$ 79.58838. The value of IT governance performance was approximately 79.6.

\subsection{DISCUSSION OF RESULTS}

Because there are four objectives, the maximum score is 100 and the minimum score is 20 , it is possible to consider 60 to be an average score that indicates regular/medium/good performance.

According to the sample of the sector of the Brazilian financial institutions, it can be observed that a performance between maximum and regular is calculated to be approximately 80 points. In other words, according to how much the sector prioritizes the use of IT in its activities, it has apparently achieved a satisfactory and effective result.

Regarding the aspects that an organization considers as the most important, such as the use of IT for growth and increased business flexibility, there should be more efforts to achieve results. As demonstrated by Canton (2008), in 2010, it was expected that the banks were more concerned about meeting legal requirements, such as Basiléia II. This finding would mean that ITG performance has found its place; however, there are still blanks to be filled to achieve a maximum score, such as looking for a better use of IT in the cost/benefit relationship of activities and use of assets, that would generate higher business value and improve resource management.

In the survey developed by Weill and Ross (2004), who considered 256 Gartner EXP worldwide member companies, the average score was 69, and one-third of the companies

\footnotetext{
${ }^{4}$ Gartner, Executive Program of Gartner Inc., Company of survey and global consultancy about IT for companies. Founded in 1979, located in Stamford, Connecticut, EUA, present in 80 countries, with more than 4300 employees and partners.
} 
scored above 74. In Brazil, Gama and Martinello (2006) conducted a study and concluded that only $10 \%$ of the 30 companies surveyed presented an ITG level lower than 70.

In achieving approximately 79.6 points, the Brazilian financial institutions show that there is a bias towards a positive evolution in the performance of IT governance; however, it is possible to question how fast it is really happening and whether the relevant elements will also undergo changes over time.

\section{CONCLUSIONS}

The present study measured the IT governance performance of financial institutions operating in Brazil using a sample of professionals in the area. The samples used consist mostly of operational bank workers who have worked for their company for more than 5 years and are part of the IT team. The relevance given to the use of IT for decision making, flexibility, growth, and resource management were mostly considered to be very high. Nevertheless, IT's influence on final performance, which generates company results in the above mentioned perspectives, did not reach its maximum performance, a factor that is possible to identify by a score of approximately 79.6. It is important to highlight that the IT Governance concept is still new and that its practice and theoretic basis are still being developed. In this respect, the present paper is relevant because its results can help understand how this administrative practice is being developed in Brazil.

Theoretically, topics on IT governance are infrequently presented by schools and scholars, and a large part of the material available is informal.

Regarding the empirical aspect, although the intention is to analyze the sector as a whole, the low level of diversity in the financial institutions and academic background of the respondents must be considered. Another limitation of the study is the low index of answers, which is most likely related to the respondents' pre-disposition towards the topic or the lack of influence on entities related to the theme, which could be assisted. In this manner, it was not possible to use a probable sample and attribute results for only the sample elements.

The main contribution of this research is the application of a significant method that provides a benchmark for an important area of economy. The results reflect some type of reliability for IT governance in financial institutions. The research can be considered a significant point for attracting investments to the sector. Scientifically, it can be a basis for further studies or comparisons over time considering the impacts of IT on society.

From the present study's results and limitations, some points appeared that could be interesting for future studies, including a deeper investigation of the themes identified in the literature review that have yet to be adequately explored, such as the issue of IT implementation and its barriers. Another possibility could be to identify the relationship between performance in each IT governance domain and global performance. The financial variables needed to prove influences on organizations' accounting sector, which could also be studied.

For future works, another suggestion is an exploratory work that conducts an in-depth interview with employees of a major financial institution to further explain the answers obtained in this survey. Finally, this study could be redone in different countries, sectors, or estates, aimed at making comparisons and thus clarifying the real scenario of IT Governance implementation and performance. 


\section{REFERENCES}

ABBC (2008) Associação Brasileira de Bancos. Relatório anual. Recuperado em 25 maio 2010, de http://www.abbc.org.br/abbc/web/arquivos/relatorio_2008_final.pdf

Afzali, P., Azmayandeh, E., Nassiri, R., Shabgahi, G. L. (2010). Effective governance through simultaneous use of COBIT and val IT. Proceedings of the International Conference on Education and Management Technology, 2, 46-50.

Albertin, A. L., Albertin, R. M. (2008). Benefícios do uso de tecnologia de informação para o desempenho empresarial. Revista de Administração Pública, 42(2), 275-302.

Arruda, P. A. F., Silva Filho, J. B. (2006). Governança de tecnologia da informação para micro e pequenas: Estudo de caso na cidade de Fortaleza. Anais do XXVI ENEGEP, Fortaleza, CE.

Ayat, M., Masrom, M., Sahibuddin, S. (2011). Issues in implementing it governance in small and medium enterprises. Proceedings of the 2nd International Conference on Intelligent Systems, Modelling and Simulation (ISMS), Phnom Penh, Cambodia.

BCB (2007). Banco Central do Brasil. Banco Múltiplo: Definição. Recuperado em 31 maio 2010, de http://www.bacen.gov.br.

Bin-Abbas, H.; Bakry, S. H. (2014). Assessment of IT governance in organizations: A simple integrated approach, Computers in Human Behavior, Volume 32, March 2014, Pages 261-267, ISSN 0747-5632, http://dx.doi.org/10.1016/j.chb.2013.12.019.

Blass, L. M. S. (1993). Automação bancária, práticas e representação. São Paulo em Perspectiva, 7(4), 81-89.

Bowen, P. L., Cheung, M. D., \& Rohde, F. H. (2007). Enhancing IT governance practices: A model and case study of an organization's efforts. International Journal of Accounting Information System, 8(3), 191-221.

Butler, R., \& Butler, M. (2010). Beyond King III: Assigning accountability for IT governance in South African enterprises. South African Journal of Business Management, 41(3), 33.

Canton, E. P. (2008). Governança de TI nas instituições financeiras no Brasil: Uma avaliação de tendências. Dissertação (mestrado), Centro Estadual de Educação Tecnológica Paula Souza, São Paulo, SP.

COBIT 5 (2013): A business framework for the governance and management of enterprise IT. Information System Audit and Control Association. <http://www.isaca.org/cobit>

Cordenonsi, J. L. (2004). Um modelo de administração da tecnologia da informação. São Paulo: Atlas.

CPqD. (2010). Banco do Futuro: Tecnologia para excelência bancária. Recuperado em 24 maio 2010, de http://www.cpqd.com.br/ofertas-relacionadas/247-temas-estruturantes/4731-banco-dofuturo.html

Dalmazo, M. S. (2005). A evolução do atendimento bancário: A importância do marketing dentro das instituições financeiras. Trabalho de conclusão de curso, Centro Universitário Nove de Julho, São Paulo, SP.

DEBAN (2009). Banco Central do Brasil, Departamento de Operações Bancárias e de Sistema de Pagamentos. Sistema de pagamentos brasileiro. Disponível em: http://www.bacen.gov.br. Brasília, DF 
De Haes, S.; Grembergen, W. V., (2008) Analysing the Relationship between IT Governance and Business/IT Alignment Maturity, Hawaii International Conference on System Sciences, Proceedings of the 41st Annual, vol., no., pp.428,428, 7-10 Jan. 2008

doi: 10.1109/HICSS.2008.66

Economics \& Statistics Administration. (2003). Digital economy 2003. Washington, DC: US Department of Commerce.

FEBRABAN (2010a) Federação Brasileira de Bancos. Portal de informações do setor. Recuperado em 25 maio 2010, de http://www.febraban.org.br

FEBRABAN (2010b) Federação Brasileira de Bancos. O setor bancário em números. $\begin{array}{lllll}\text { Recuperado em } & 24 & \text { maio } & 2010, & \text { de }\end{array}$ http://www.febraban.org.br/acervo.asp?id_pagina=85\&id_paginaDe=78\&id_texto=

FEBRABAN (2010c) Federação Brasileira de Bancos. SWIFT. Recuperado em 24 maio 2010, de http://www.febraban.org.br/Febraban.asp?modulo=Servi\%E7os\&id_pagina=110

Gama, F. A., \& Martinello, M. (2006). Governança de tecnologia da informação: Um estudo em empresas brasileiras. Trabalho apresentado no 4o Simpósio FUCAPE, Vitória, ES.

Gheorghe, M., Nastase, P., Boldeanu, D., \& Ofelia, A. (2009). IT Governance in Romania: A case study. Global Economy Journal, 9(1), 1-13.

IBGE (2004). Instituto Brasileiro de Geografia e Estatística. CNAE - Classificação Nacional de Atividades Econômicas. Recuperado em 10 novembro 2009, de http://www.cnae.ibge.gov.br/

IBGC (2007). Instituto Brasileiro de Governança Corporativa. Código de melhores práticas de governança corporativa (3a ed.). São Paulo: IBGC.

IBGC (2009) Instituto Brasileiro de Governança Corporativa. Governança corporativa. Recuperado em 26 novembro 2009, de http://www.ibgc.org.br/Secao.aspx?CodSecao=17

ITGI (2003) IT Governance Institute. Board briefing on IT Governance (2nd ed.). Rolling Meadows, IL: ITGI.

ITGI (2008) IT Governance Institute. Unlocking value: An executive primer on the critical role of IT governance. Rolling Meadows, IL: ITGI.

ITIL (2013). Information Technology Infrastructure Library, the British Office of Government Commerce. <www.itil.org>

Jairak, K.; Praneetpolgrang, P.; (2013) Applying IT governance balanced scorecard and importance-performance analysis for providing IT governance strategy in university, Information Management \& Computer Security, Vol. 21, 4, pp. 228 - 249

Jong, F., Van Hillegersberg, J., Van Eck, P., Van Der Kolk, F., \& Jorissen, R. (2010). Governance of offshore IT outsourcing at shell global functions IT-BAM development and application of a governance framework to improve outsourcing relationships. In: W. van der Aalst, J. Mylopoulos, M. Rosemann, M. J. Shaw, C. Szyperski (Series Eds.), I. Oshri, \& J. Kotlarsky (Vol. Eds.), Lecture notes in business information processing: Vol. 55. Global sourcing of information technology and business processes (pp. 119-150). Berlin: Springer.

Jordan, E., \& Musson, D. (2004). Corporate Governance and IT Governance: Exploring the board's perspective. Proceedings of the ACIS, Sydney, Australia.

Ko, D., \& Fink, D. (2010). Information technology governance: An evaluation of a theorypractice gap. Corporate Governance, 10(5), 662-674. 
Krey, M., Keller, T., Harriehausen, B., \& Knoll, M. (2011). Towards a classification of information technology governance frameworks for the development of a IT GRC healthcare framework. IEEE International Workshop on Consumer eHealth Platforms, Services and Applications, 1, 34-38.

Lin, F., Chou, S., \& Wang, W. K. (2011). IS practitioners views on core factors of effective IT governance for Taiwan SMEs. International Journal of Technology Management, 54(2), 256269.

Lunardi, G. L.; Becker, J. L.; Maçada, A. C. G.; Dolci, P. C. (2014) The impact of adopting IT governance on financial performance. A impirical analysis among Brazilian firms. International Journal of Accounting Information Systems, Volume 15, Issue 1, March, Pages 66-81

Lunardi, G. L., Dolci, P. C., Becker, J. L., \& Gastaud, A. C. (2007). Governança de TI no Brasil: Uma análise dos mecanismos mais difundidos entre as empresas nacionais. Trabalho apresentado no Simpósio de Excelência em Gestão e Tecnologia, Rio Grande do Sul, RS.

Malhotra, N. K. (2001). Pesquisa de marketing: Uma orientação aplicada. Porto Alegre, RS: Bookman.

Mansur, R. (2007). Governança de TI: Metodologia, frameworks e melhores práticas. Rio de Janeiro, RJ: Brasport.

Nfuka, E. N., \& Rusu, L. (2011). The effect of critical success factors on IT governance performance". Industrial Management \& Data Systems, 111(9), 1418-1448.

OECD (2004), Principles of Corporate Governance. OECD. Available on <http://www.oecd.org/corporate/oecdprinciplesofcorporategovernance.htm>. Retrieved 201406-24.

Peck, P. (2006, 17 janeiro). Quais são os impactos legais da Sarbanes-Oxley no Brasil? CIO. Recuperado em 24 maio 2009, de http://cio.uol.com.br/gestao/2006/01/18/idgnoticia.2006$0118.5258602125 /$

Richardson, R. J. (1999). Pesquisa social: Método e técnicas. São Paulo, SP: Atlas.

Schwarz, A., \& Hirschheim, R. (2003). An extended platform logic perspective of IT governance: Managing perceptions and activities of IT. Journal of Strategic Information System, 12(2), 129-166.

Simonsson, M., Johnson, P., \& Ekstedt, M. (2010). The effect of IT Governance maturity on IT Governance performance. Information Systems Management, 27(1), 10-24.

Tapajós, U. (2008). Governança de TI com ITIL® (Vol. 3). São Paulo, SP: CompanyWeb.

Toledo, L. G. (1993). Marketing bancário: Análise, planejamento, processo decisório. São Paulo, SP: Atlas.

Van Grembergen, W. (2004). Strategies for information technology governance. Hershey, PA: Idea Group.

Van Grembergen, W., De Haes, S., \& Guldentops, E. (2004). Structures, processes and relational mechanisms for IT Governance. In W. Van Grembergen (Ed.), Strategies for information technology governance (pp. 1-36). Hershey, PA: Idea Group.

Weill, P., \& Broadbent, M. (2003). Creating effective IT Governance: A Gartner EXP Premier Survey Report. Stamford, CT: Gartner.

Weill, P., \& Ross, J. (2004). IT Governance: How top performers manage IT decision rights for superior results. Boston, MA: Harvard Business School Press. 
Weill, P., \& Ross, J. (2005). A matrixed approach to designing IT Governance. MIT Sloan Management Review, 46(2), 26-34.

Wilkin, C., \& Chenhall, R. (2010). A review of IT Governance: A taxonomy to inform accounting information system. Journal of Information System, 24(2), 107-146.

Young, R. (2009, 25 agosto). Pesquisa: Falha em TI reduz até 2\% o valor de ações negociadas em bolsa. e8Consulting: CIO. Recuperado em 20 novembro de 2009, de http://cio.uol.com.br/opiniao/2009/08/25/pesquisa-falha-em-ti-reduz-ate-2-o-valor-de-acoesnegociadas-em-bolsa/ 